\title{
IDENTIFYING ROOT CAUSES OF CONFLICTS AT FARM LEVEL AND CONFLICTS RESOLUTION STRATEGIES IN PUNJAB, PAKISTAN
}

\author{
aSohaib Usman*, aAqeela Saghir, aKhalid Mahmood Ch. bRakhshanda Kousar, ${ }^{\text {bRaza Ullah }}$ \\ ${ }^{a}$ Institute of Agricultural Extension, Education and Rural Development, University of Agriculture Faisalabad \\ ${ }^{b}$ Institute of Agricultural and Resource Economics, University of Agriculture Faisalabad.
}

\section{ART ICLE IN F O}

\section{Article History}

Received: December 02, 2020

Revised: June 26, 2021

Accepted: August 25, 2021

\section{Keywords}

Conflicts

Conflict resolution

Consequences

Farm families

Negotiation
A B S T R A C T

The present study was conducted in three districts of the Punjab province. Muzaffargarh district from southern Punjab, Gujranwala district from center, and Attock district from North were selected randomly from three different zones (South, North, and Central Punjab) of Punjab, Pakistan. In each district, 200 farm families (100 male and 100 female) were selected purposively (involved in the conflict) for data collection rationally with help of key informants hence the total sample size was 600 in three selected districts. A well-planned and well-structured interview schedule was prepared for the collection of data. Two focus group discussions were planned for an in-depth discussion in each district. Each focus group consisted of 8 to10 members. Results indicate that passageway among agricultural land $(\bar{x}=3.73)$, water distribution at farm level $(\bar{x}=3.64)$, crop destroyed by the animals $(\bar{x}=3.47)$, and burning of crops $(\bar{x}=3.34)$ were the major causes of conflicts at the farm level as perceived by the respondents. Wastage of money and time ( $\bar{x}=3.74)$, affects daily routine life $(\bar{x}=3.72)$, affects child education $(\bar{x}=3.63)$, affects the marriage of the family members $(\bar{x}=3.52)$ and less farm production $(\bar{x}=3.32)$ and family break up $(\bar{x}=3.27)$ were the consequences of farm-level conflicts. Participation of elder family member $(\bar{x}=3.69 / 5.00)$, negotiation among the conflicted parties $(\bar{x}=3.49 / 5.00)$, use of local politicians $(\bar{x}=3.41 / 5.00)$, social relationship $(\bar{x}=3.35 / 5.00)$, involvement of informal judiciary (panchayat) $(\overline{\mathrm{x}}=3.20 / 5.00)$ were the modalities used by the local communities for conflicts resolution as perceived by the respondents. It was recommended that local panchayat and local administrative bodies should be promoted in the conflict management process.

Corresponding Author: Sohaib Usman

Email: sohaibusmancheema174@gmail.com

(C) The Author(s) 2021.

\section{INTRODUCTION}

Conflicts in a society are natural occurring process of individual's life. It may happen in every walk of life where the individual has disagreements in human interactions. It involved disharmony, fight, tussle, smash, intense discussion, squabbling and uniform hot battle or fighting among individual or groups. Conflicts among individuals or groups manifested in different situations like interpersonal misunderstanding, differences in ideas over an issue, gap between understanding an idea, conflicts over supremacy, authority and control over social problems (Brahnam et al., 2005). Conflicts in a society start with disagreements or differences among two or more than two individual parties, societal group, family unit or regions (Dzurgbe, 2006). Conflict is a supposed struggle between the inter-reliant persons 
over contradictory inequalities that stroked in notions, ethics, and beliefs, views and objectives. It may start with respect and esteem, control and powers and associations (Wilmot and Hocker, 2010). Conflicts stem out from different roots; it may start with human behavior, competition and race among individuals or group of individuals for access of resources and authority. It arises with different social designs, unescapable tussles among the different group of the society, organizational associations and different class of society. Moreover, believes, values, cultural background, communication styles, mode of interactions, emotions, selective behavior, characteristics and norms toward society are the root causes of conflicts among individuals (Namande, 2008).

Conflicts are common problem among individuals especially at farm level. Disputes, clashes, conflicts or differences exist between two or more parties. There is a difference between different mentalities of people in the same society especially in rural areas because they have different schools of thought and peer groups that may causes of conflicts (Huth et al., 2017). In developing countries, the limited supply of resources, the proportion of illiterate farmers is high, different way of thinking, education, maturity level, religious values, lifestyle, principles, social values, cultural values, beliefs, cultural practices, attitude of adopting of agricultural innovation and their ancestors' agricultural practices are different that may lead to conflict situation. Conflicts among the farming community at farm level affect the farm activities and farm production (Shan et al., 2017).

According to Usman et al. (2020) in Punjab, Pakistan the conflicts especially in rural areas among farming communities started with the unequal distribution of water at farm level, passage way among cultivated land, crop destroyed by animals, burning of crop by the opponents, right of women in ancestors land distribution and use of family land without permission that may affect farm production. Multi-actor such as local leaders, politicians, social worker, local administrative authority play their active role in conflict management by using innovative as well as traditional resolution modalities such as compensation, arbitration, mediation and negotiation etc.

There are different perceptions about conflicts in the farming community, such as positive conflicts that create a competitive environment as well as negative conflicts that affect negatively on society. Conflicts among farmers and herdsman resolved through the active and encouraging involvement of different stakeholders (Bello, 2013). It was concluded that family violence and conflicts effect both men and women and they face physical, social and financial issues, conflicts which can lead to some events that may result in some instability and affects an individual's ability to work and perform daily tasks (Dadashpoor and Ahani, 2019).

\section{METHODOLOGY}

The study was conducted in three districts of the Punjab province. Muzaffargarh district from southern Punjab, Gujranwala district from central Punjab and Attock district from northern Punjab were selected randomly from three different zones (South, North and Central Punjab) of Punjab province, Pakistan. Sugarcane, wheat, cotton, rice are the major crops in study area, while mustard, rape seed, sunflower and canola are also cultivated as oilseed crops was cultivated on limited area as minor crop. Beside this bajra, jawar, lucerne and maize are also grown as fodder crop. Perennial and nonperianal canal water with supplement tube-well is the main source of irrigation in district Muzaffargarh and Gujranwala while in Attock rain water was the main source of irrigation.

\section{Sampling selection}

There was no previous record of the framers involved in conflicts at farm level in the study area and population in the selected three districts (Gujranwala, Muzaffargarh and Attock) was unknown. In each district 200 farm families (100 male and 100 female) were selected purposively (involved in conflict) for data collection rationally with the help of local key informant (local leader, extension field staff, social workers) in each district. Hence the sample size of 600 respondents in three districts was selected to compare the results in three different zones.

\section{Research instrument}

A well planned and well-structured interview schedule was prepared for collection of data inline to study objectives. The interview schedule was pretested to check its validity and reliability through Cronbach alfa value used as the scale to check the consistency and internal reliability and by discussion with the expert from Institute of Agricultural Extension, Education and Rural Development, University of Agriculture Faisalabad. 


\section{Data collection and analysis}

The data were collected through face-to-face interview technique. Both quantitative and qualitative responses were recorded. The qualitative data were used for the triangulation purpose. The qualitative comments as derived from the respondents were used to endorse the quantitative findings. Quantitative data were analyzed by using Statistical Package for Social Sciences (SPSS) while qualitative data was analyzed by using content analysis method.

\section{RESULTS AND DISCUSSION}

Analysis, results and interpretation of the collected data are most significant steps in social sciences research for drawing the conclusion and recommendations. Generalization and prediction cannot conquer without the results and discussion (Bavdekar, 2015).

Keeping in view the importance and its significant characteristics the results, the findings are tabulated and interpreted. The causes of the conflicts as perceived by the respondents is given in Table 1.

Table 1. Distribution of the respondents according to reasons of conflicts.

\begin{tabular}{lcccc}
\hline Causes of conflicts & Weighted score & Std. Deviation & Mean & Rank order \\
\hline Passage way among agriculture land & 1738 & 0.941 & 3.73 & 1 \\
Water distribution at farm level & 1764 & 0.975 & 3.64 & 2 \\
Crop destroyed by the animals & 1753 & 0.996 & 3.47 & 3 \\
Burning of crops & 561 & 1.093 & 3.34 & 4 \\
Inter marriage system & 1559 & 1.007 & 3.33 & 5 \\
Loan on agricultural land & 1530 & 1.058 & 3.26 & 6 \\
Unequal and biased distribution & 1517 & 1.054 & 3.20 & 7 \\
Late availability of rights & 1315 & 1.003 & 3.15 & 8 \\
Adoption of innovation & 1301 & 1.083 & 3.08 & 9 \\
Ancestors' cultivation methods & 1271 & 1.008 & 3.06 & 10 \\
Local level corruption & 1285 & 0.996 & 3.05 & 11 \\
Mutual farming & 1217 & 1.029 & 3.03 & 12 \\
Relationships between families & 1258 & 0.936 & 3.02 & 13 \\
Authority and power (Numberdari) & 1233 & 1.144 & 3.01 & 14 \\
Commercialization of ancestors' land & 1201 & 1.118 & 2.99 & 15 \\
Caste inequality & 1212 & 0.991 & 2.99 & 16 \\
Clash over access of natural resources & 1136 & 1.014 & 2.97 & 17 \\
Conflict over access to fertile land & 1163 & 1.033 & 2.94 & 18 \\
Conflict over use of labour force & 1051 & 1.034 & 2.94 & 19 \\
Abuses at farm & 1124 & 1.133 & 2.92 & 20 \\
Gender discrimination & 1105 & 0.997 & 2.92 & 21 \\
Inequality in conflict resolution & 1182 & 1.006 & 2.90 & 22 \\
Harassment & 1068 & 1.102 & 2.86 & 23 \\
Rude Attitude and behavior & 1121 & 1.061 & 2.85 & 24 \\
Ego & 996 & 1.131 & 2.78 & 25 \\
\hline
\end{tabular}

Table 1 reveals the different causes of conflicts at farm level among the farming communities. According to the results passage way among agricultural land was at 1st rank according to the mean value and std. deviation $(\bar{x}=3.73 \pm 0.941)$, water distribution of water at farm level was at 2 nd rank order with the mean value and standard deviation ( $\bar{x}=3.64 \pm 0.975)$, while crop destroyed by the wondering animals was at 3rd rank order according to the mean value and standard deviation $(\overline{\mathrm{x}}=3.47 \pm 0.996)$, burning of crops was at 4th rank according to the mean value and standard deviation ( $\bar{x}=3.34 \pm 1.093)$. Respondents also described that intermarriage system among farm families was also the causes of conflicts and it was at rank 5th with mean value and standard deviation $(\overline{\mathrm{x}}=3.33 \pm 1.007)$. As the respondents described in focus group discussion that loan on agriculture land, distribution according to different political group, late availability of right, adoption of innovation and 
ancestor's cultivation methods are the factor responsible for farm level conflicts. Furthermore, they also described that local level corruption in agriculture departments and mutual farming in rural area among the small land holders was also the root causes of conflicts among framing community. The study results were much similar to Usman et al. (2020) who concluded that burning of crops, loan on agriculture land, intermarriage system, water distribution at farm level, passage way among agricultural land and crop destroyed by animals are the root causes of conflicts in Punjab Pakistan.

One of the respondents in focus group discussed that:

"Once I was irrigating my land, and I have 20 minute of canal water according to local warrabandi (water distribution system at farm level) but my neighbor farmer started quarrel and shouting at me because he was claiming that my irrigation time is over now, the patience among farming community is over now and clash at farm level is increasing day by day".

According to the results relationship among family members, access toward authority and power and commercialization of agricultural land was at rank 13th, 14th and 15th according to their mean values and standard deviation $(\bar{x}=3.02 \pm 0.936),(\bar{x}=3.01 \pm 1.14)$ and $(\bar{x}=2.99 \pm 1.18)$ respectively. Some stakeholder in the focus group discussion discussed that conflict over access to fertile land among the ancestors' land distribution, utilization of natural resources and use of labour force in mutual farming system are also the significant issues of conflicts in the study areas. They also described those abuses at farm, gender discrimination at farm level, inequality in conflict resolution, sexual harassment at farm level, rude behavior toward other farmers and ego at farm level was contributing in reasons of conflicts at farm level. Yamano and Deininger (2005) also work on land related conflicts in Kenya concluded that mostly conflicts start with relatives over land boundaries and conversion of agricultural land into commercialization due to high papulation stress.

One of the young respondents in focus group discussion described that:

"I have conflict with my brother over the distribution of ancestor's land he was demanding to get the fertile land that was nearest to the village and was productive land, that conflict cause hurdle in our family marriage and relationship with my blood relatives."

The study results are similar to the (Manu et al., 2014) as he discussed that the inter cast marriage system and water distribution at the farm level were the main causes of farm conflicts. He opined; the persistence of these challenges could expedite the conflicts.

Table 2. Perceived holistic effects of conflicts by the respondents.

\begin{tabular}{lcccc}
\hline Holistic effects of conflicts & Weighted score & Std. Deviation & Mean & Rank order \\
\hline Wastage of money and time & 2077 & 0.928 & 3.74 & 1 \\
Affects Daily routine life & 2052 & 0.911 & 3.72 & 2 \\
Affects Child education & 1983 & 0.980 & 3.63 & 3 \\
Affects Marriage of the family members & 1801 & 0.937 & 3.52 & 4 \\
Social relationship & 1882 & 0.979 & 3.50 & 5 \\
Affects the relations among family member & 1731 & 0.966 & 3.44 & 6 \\
Less Farm production & 1599 & 0.997 & 3.32 & 7 \\
Murder & 756 & 1.128 & 3.30 & 8 \\
Family breakup & 897 & 1.070 & 3.27 & 9 \\
Extra Expenditures & 1366 & 1.040 & 3.25 & 10 \\
Judicial cases & 843 & 1.075 & 3.18 & 11 \\
Mental Depression & 1172 & 1.143 & 3.18 & 12 \\
Violence & 1339 & 0.938 & 3.17 & 13 \\
Lack of unity at farm level & 1271 & 1.052 & 3.10 & 14 \\
Children involved in labour & 1147 & 1.061 & 3.10 & 15 \\
Displacement from their homes & 1105 & 0.983 & 3.01 & 16 \\
\hline
\end{tabular}

Table 2 describes the holistic effects of the farm level conflicts on farm families that was wastage of money and time which was 1 st rank with mean value and standard deviation of $(\overline{\mathrm{x}}=3.78 \pm 0.928)$. This implies that if the farmers involved in conflict, they have to spend lot of money and extra time to persuade his case in the 
court and local police station. Conflicts at farm level among farming community also affect the daily routine life and education of their children due to high depression and tension and it was at rank 2nd and 3rd with mean value and standard deviation $(\bar{x}=3.72 \pm 0.911)$ and $(\bar{x}=3.63 \pm 0.980)$ respectively.

One of the key informants commented that: "I had a case in court regarding the ancestor's land dispute among family members. I spend a lot of money and time on my case. Even after 7 year I did not get any decision regarding my land right. Now I have no more money to purchase inputs (fertilizer, pesticide and operational equipment) to run my farm activities. I am not able to take up my farm operations and failed to invest in my farm as per need that may result in low production".

Key informant in the focus group also described that in our area farm level conflicts disturbed our family relationship as well as it affects the marriage of our children even after the resolution of conflicts. He also committed that further leading conflicts in rural area also damage the social relationship with the other community member. The results were in line with (Siddik et al., 2018) who reported that conflicts resulted in financial loss, hampered social status, and affect the relationship between plaintiff and defendant.

Less farm production, murder and family break up was ta ranking $7^{\text {th }}, 8^{\text {th }}$ and $9^{\text {th }}$ with mean value and standard deviation $\quad(\overline{\mathrm{x}}=3.32 \pm 0.997), \quad(\overline{\mathrm{x}}=3.30 \pm 1.128) \quad$ and $(\bar{x}=3.27 \pm 1.070)$ respectively. A conflict at farm level in the rural areas adversely affects the farm production due to low investment and extra expensive in judiciary cases. Furthermore, it was concluded that clashes in rural community cause mental depression and sickness among the two parties (Usman et al., 2020).

One of the respondents committed:

"A year ago, I have conflict with my neighbor farmers over land boundary and land measurement. I put a case against him in court. I can't pay full attention to my farm activities and I was unable to harvest my crop on time the result of such negligence was less farm production and extra expensive. Even after a year I can't get final decision about my case."

Mental depression, violence in the rural society, lack of farm unity was at rank $12^{\text {th }}, 13^{\text {th }}$ and $14^{\text {th }}$ with mean value and standard deviation ( $\overline{\mathrm{x}}=3.18 \pm 1.143)$, $(\bar{x}=3.17 \pm 0.938)$ and $(\bar{x}=3.10 \pm 1.052)$ respectively. It implies that some serious conflicts cause mental sickness due to limited resources and more expensive by the small farmers involved in such conflicts. Furthermore, children involved in labour and displacement from their ancestor's home were at rank 15 th and 16th with mean value and standard deviation $(\bar{x}=3.10 \pm 1.061)$ and $(\bar{x}=3.01 \pm 0.983)$ respectively. The results are less or more similar with those of Fazal (2009) who describes that conflict adversely affects their crops and livestock. This also results in the huge displacement of the local farmers and it also affects the socio-economic of the host population in the displacement area that may lead further conflicts.

Table 3 show the district-wise comparison of respondents with respect to their opinion against reasons of conflict at farm level as p-value is $<0.05$ shows that there is significant difference among the three districts regarding their perception about burning of crops is an issue of conflict at farm level. Differences in mean value indicate that 'burning of crop' was major cause of conflict in Attock ( $\bar{x}=3.78 \pm 0.130)$ district as compared to Gujranwala $(\overline{\mathrm{x}}=3.05 \pm 0.134)$ and Muzaffargarh ( $\overline{\mathrm{x}}=2.98 \pm 0.144)$ districts. Passage way among agriculture land was more in district Attock and district Muzaffargarh as mean values ( $\overline{\mathrm{x}}=3.88 \pm 0.087$ ) and $(\bar{x}=3.88 \pm 0.087)$ as compared to Gujranwala district while opinion against reasons of conflicts as p-value is $>0.05$ shows there is non-significant differences in three districts regarding their perception about water distribution at farm level was same in all districts. Perception of respondents about crops destroyed by animals, loan on agriculture land and intermarriage systems was root causes of conflicts among farmers in district Attock as compared to the other districts, because it shows significant differences in three district and mean values stood as $3.69 \pm 0.086,3.69 \pm 0.086$ and $3.69 \pm 0.079$, respectively. Distribution according to different political group was major issues of conflicts in district Gujranwala $(\overline{\mathrm{x}}=3.40 \pm 0.074)$ and Attock $\bar{x}=3.60 \pm 0.087$ as compared to district Muzaffargarh $(\bar{x}=2.75 \pm 0.075)$. Furthermore, adoption of innovation, authority and power, ancestor's cultivation method, commercialization of ancestors' land and abuses at farm level show significant differences in three districts because it has $\mathrm{p}<0.05$, it was highly existing in Attock district as compared to other two districts according to the high mean values. According to respondent's perception ego ( $\bar{x}=3.32 \pm 0.103)$, harassment at farm $(\bar{x}=3.33 \pm 0.100 \mathrm{~A})$, rude attitude and behavior 
$(\overline{\mathrm{x}}=3.38 \pm 0.112 \mathrm{~A})$ was wider root causes of conflicts in district Attock and as compared in Gujranwala and Muzaffargarh districts. The results were in line with (Ofuoku and Isife, 2009) who concluded that crop destruction by the animals, sexual harassment of women by the host, cattle theft, stray cattle and indiscriminate bush burning was the major reasons of conflicts among framers. The study results were less or much similar to Gehrig and Rogers (2009) who described that there are various factors responsible for conflicts like affiliation with a specific political group, struggle and power, corruption, access to asserts ethnic and tribal status and gender decimations. Neef et al. (2004) concluded that mostly conflicts at farm level starts with inadequate distribution of water. People who have strong background and have power and authority can get water from reservoirs and are capable to usage lawful diversity at communal level for their personal usage.

Table 3. District-wise comparison of respondents with respect to their opinion against reasons of conflict at farm level.

\begin{tabular}{lllll}
\hline \multicolumn{1}{c}{ Reasons of conflicts at farm level } & \multicolumn{3}{c}{ Districts } & \multirow{2}{*}{ P-value } \\
\cline { 2 - 4 } & Gujranwala & Muzaffargarh & Attock & \\
Burning of crops & $3.05 \pm 0.134 \mathrm{~B}$ & $2.98 \pm 0.144 \mathrm{~B}$ & $3.78 \pm 0.130 \mathrm{~A}$ & $0.0000^{* *}$ \\
Passage way among agriculture land & $3.51 \pm 0.069 \mathrm{~N}$ & $3.81 \pm 0.070 \mathrm{~A}$ & $3.88 \pm 0.087 \mathrm{~A}$ & $0.0015^{* *}$ \\
Water distribution at farm level & $3.52 \pm 0.069 \mathrm{~A}$ & $3.66 \pm 0.075 \mathrm{~A}$ & $3.76 \pm 0.085 \mathrm{~A}$ & $0.1036 \mathrm{~ns}$ \\
Crop destroyed by the animals & $3.43 \pm 0.076 \mathrm{~B}$ & $3.34 \pm 0.068 \mathrm{~B}$ & $3.69 \pm 0.086 \mathrm{~A}$ & $0.0042^{* *}$ \\
Loan on agricultural land & $3.21 \pm 0.089 \mathrm{~B}$ & $2.92 \pm 0.069 \mathrm{C}$ & $3.69 \pm 0.086 \mathrm{~A}$ & $0.0000^{* *}$ \\
Inter marriage system & $3.41 \pm 0.084 \mathrm{~B}$ & $3.02 \pm 0.071 \mathrm{C}$ & $3.69 \pm 0.079 \mathrm{~A}$ & $0.0000^{* *}$ \\
Distribution according to politicians' group & $3.40 \pm 0.074 \mathrm{~A}$ & $2.75 \pm 0.075 \mathrm{~B}$ & $3.60 \pm 0.087 \mathrm{~A}$ & $0.0000^{* *}$ \\
Adoption of innovation & $3.03 \pm 0.077 \mathrm{~B}$ & $2.70 \pm 0.082 \mathrm{C}$ & $3.67 \pm 0.092 \mathrm{~A}$ & $0.0000^{* *}$ \\
Authority and power & $2.95 \pm 0.090 \mathrm{~B}$ & $2.64 \pm 0.082 \mathrm{C}$ & $3.59 \pm 0.106 \mathrm{~A}$ & $0.0000^{* *}$ \\
Ancestors' cultivation methods & $3.07 \pm 0.078 \mathrm{~B}$ & $2.71 \pm 0.073 \mathrm{C}$ & $3.60 \pm 0.090 \mathrm{~A}$ & $0.0000^{* *}$ \\
Commercialization of ancestors' land & $2.99 \pm 0.097 \mathrm{~B}$ & $2.61 \pm 0.080 \mathrm{C}$ & $3.59 \pm 0.098 \mathrm{~A}$ & $0.0000^{* *}$ \\
Abuses at farm & $3.04 \pm 0.101 \mathrm{~B}$ & $2.44 \pm 0.076 \mathrm{C}$ & $3.59 \pm 0.104 \mathrm{~A}$ & $0.0000^{* *}$ \\
Ego & $2.98 \pm 0.110 \mathrm{~B}$ & $2.36 \pm 0.082 \mathrm{C}$ & $3.32 \pm 0.103 \mathrm{~A}$ & $0.0000^{* *}$ \\
Sexual harassment & $2.84 \pm 0.112 \mathrm{~B}$ & $2.60 \pm 0.081 \mathrm{~B}$ & $3.33 \pm 0.100 \mathrm{~A}$ & $0.0000^{* *}$ \\
Rude attitude and behavior & $2.87 \pm 0.088 \mathrm{~B}$ & $2.60 \pm 0.075 \mathrm{C}$ & $3.38 \pm 0.112 \mathrm{~A}$ & $0.0000^{* *}$
\end{tabular}

Ns = Non-significant $(\mathrm{P}>0.05) ;{ }^{*}=$ Significant $(\mathrm{P}<0.05) ;{ }^{* *}=$ Highly significant $(\mathrm{P}<0.01) \quad$ Means sharing similar letters in a row are statistically non-significant $(\mathrm{P}<0.05)$

Table 4 District-wise comparison of respondents with respect to their opinion against "the strategies are valuable to conflict resolution".

\begin{tabular}{lllll}
\hline Strategies used for conflicts resolution & \multicolumn{2}{l}{ District } & P-value \\
\cline { 2 - 3 } & Gujranwala & Muzaffargarh & Attock & \\
\hline Negotiations among conflicted parties & $3.60 \pm 0.054 \mathrm{~B}$ & $3.07 \pm 0.065 \mathrm{C}$ & $3.89 \pm 0.070 \mathrm{~A}$ & $0.0000^{* *}$ \\
Use local politicians to settle down the conflicts & $3.41 \pm 0.071 \mathrm{~B}$ & $3.12 \pm 0.068 \mathrm{C}$ & $3.80 \pm 0.082 \mathrm{~A}$ & $0.0000^{* *}$ \\
Involve the local panchayat & $3.12 \pm 0.093 \mathrm{~B}$ & $3.07 \pm 0.066 \mathrm{~B}$ & $3.58 \pm 0.087 \mathrm{~A}$ & $0.0000^{* *}$ \\
Participation of elder family members & $3.50 \pm 0.074 \mathrm{~B}$ & $3.69 \pm 0.072 \mathrm{~B}$ & $3.91 \pm 0.073 \mathrm{~A}$ & $0.0007^{* *}$ \\
Social relationships & $3.28 \pm 0.074 \mathrm{~B}$ & $2.97 \pm 0.075 \mathrm{C}$ & $3.88 \pm 0.082 \mathrm{~A}$ & $0.0000^{* *}$ \\
Education to understand the conflicts laws & $3.31 \pm 0.083 \mathrm{~B}$ & $3.12 \pm 0.068 \mathrm{~B}$ & $3.69 \pm 0.079 \mathrm{~A}$ & $0.0000^{* *}$ \\
\hline
\end{tabular}
NS = Non-significant $(\mathrm{P}>0.05) ;{ }^{*}=$ Significant $(\mathrm{P}<0.05) ;{ }^{* *}=$ Highly significant $(\mathrm{P}<0.01)$, Means sharing similar letters in a row are statistically non-significant $(\mathrm{P}<0.05)$.

Table 4 results shows opinion against the strategies used for conflicts resolution as p-value less than 0.05; this shows that there is significant difference among the three districts regarding their perception about negotiation among conflicted parties was conflicts management strategy. Mean value indicated that negotiations among conflicted parties' techniques were used widely in Attock $(\overline{\mathrm{x}}=3.89 \pm 0.070)$ district as 
compared to Gujranwala ( $\overline{\mathrm{x}}=3.60 \pm 0.054)$ and Muzaffargarh $(\overline{\mathrm{x}}=3.07 \pm 0.065)$ districts. Use local politicians to settle down conflicts were also widely used for conflicts management technique in district Attock with mean value $(\bar{x}=3.80 \pm 0.082)$ as compared to Gujranwala $(\bar{x}=3.41 \pm 0.071)$ and Muzaffargarh district $(\bar{x}=3.12 \pm 0.068$ ). Result was similar to (Shah et al., 2020) who described that sometime politician play their significant role in conflict resolution process among two parties because people think that they have authority and power. In some area they only support to their own voters the chance of biasness in such cases increased that may lead further conflicts.

Involvement of local panchayat (informal administrative body for conflict resolution), participation of elder family member and use of social relation also show significant relationship. The highest mean value also show that such strategies widely followed by the stakeholders for conflict resolution in Attock district as compared to Gujranwala and Muzaffargarh districts. The results were similar to Ahmed (2009) and (Lehmann and Saran, 1975) who concluded that in Punjab Pakistan informal judiciary is known as panchayat and in Baluchistan it is known as Jirga. They used mediation, conditions based, reconciliation, compact based and intermarriage system among both parties as innovative modalities for conflicts resolution. Local informal judiciary system (panchayat) is the local institution in the south Asia responsible to settle down social and material conflicts/ disputes and maintained of rues and law in the local societies. In ancient time panchayat has power and authority to handle the wide range of issues in local community. There is low literacy level in farming community so there is need to educate farming community regarding conflicts management and conflict management laws.

Results indicates that there was significant difference among three districts regarding Respondent's perception about 'education to understand the conflicts laws' technique was also used widely in district attock $(\bar{x}=3.69 \pm 0.079)$ as compared to Gujranwala $(\bar{x}=3.31 \pm 0.083)$ and Muzaffargarh $(\bar{x}=3.12 \pm 0.068)$. In focus group discussion it was described that in district Attock mostly people follow their traditional method of conflict resolution as compared to formal judicial system because they strictly attached with their ancestors' values and cultures. The results were similar to Robertson \& Olson (2012) who reported that agricultural extension can assist people to acquire more knowledge and resources and services that will definitely escalate their productivity, wellbeing and resolution to conflicts.

One of the old respondents also committed that:

"In ancient time conflicted parties prefer to solve their conflicts by the local administration and elder family member. The decision declared by the elder family member was implemented by the both parties to maintain dignity and honor of their family member but now time has changed. People prefer to put their case in judiciary and local police station to show their priority and power."

The results were much similar to (Mehmood and Chaudhry, 2015) who concluded that mediation is historic and tactful and quick source of timely justice process at local level for conflict resolution among two parties. Mediator remains unbiased in the resolving any conflicts (Walker, 2002; Maturo et al., 2010). Apart from that, some multi-actor elder family's members, local leader (Numberdar), imam-masjid, social members and informal judiciary member (panchayat) actively participate in the conflict's resolution process and for peace building in the society (Usman, 2019).

\section{CONCLUSION AND RECOMMENDATIONS}

The study determined that water distribution at farm land, passage way among agriculture land, burning of crops by the opponents, crops destroyed by animals, inter-marriage system among farm families and loan on ancestor's land were the major issues in study area. The conflicts at farm level were common but the consequences of such farm level conflicts were horrible as it affects the daily routine life, family relationship, cause violence in the society, family relationship, extra expensive and judiciary cases. In focus group discussion it was confirm that conflicts at farm level among farming group in some serious cases it causes depression, threat of being kidnap and mental stress in the victim family. For instance, it also affects the farm activities and farm production due to little or no attention to towed farm activities. However, local leader (Numberdar), local politicians and local police station play significant role in resolution process. It is recommended that local panchayat and local administrative body should be promoted in conflict management process. Extension field staff may change the mindset of the framing 
community regarding conflicts in this regard seminar, farmer meetings should be arranged at local level.

\section{ACKNOWLEDGEMENTS}

We are thankful to the entire key informant such as political representatives, extension field staff, social workers and local leaders for their support and active participation in the process of data collection and discussion. We are grateful to the Higher Education Commission, Pakistan for the funding the project.

\section{REFERENCES}

Ahmed, M. 2009. Local-bodies or local biradari system: An analysis of the role of biradaries in the local bodies system of the Punjab. Pakistan Journal of History and Culture, 30: 81-92.

Bavdekar, S. B. 2015. Writing the discussion section: Describing the significance of the study findings. Journal of the Association of Physicians of India, 63: 40-42.

Bello, A. U. 2013. Herdsmen and Farmers Conflicts in North-Eastern Nigeria: Causes, Repercussions and Resolutions. Academic Journal of Interdisciplinary Studies.

Brahnam, S. D., T. M. Margavio, M. A. Hignite, T. B. Barrier and J. M. Chin. 2005. A gender-based categorization for conflict resolution. Journal of Management Development, 24: 197-208.

Dadashpoor, H. and S. Ahani. 2019. Land tenure-related conflicts in peri-urban areas: A review. Land Use Policy, 85: 218-29.

Dzurgbe, A. 2006. Prevention and management of conflict. Ibadan: Loud Books (Publishers), Nigeria. . Place Published.

Fazal, M. 2009. Impact of war in Swat valley on agriculture sector. (Islamabad: AIRRA, 2009), p.32. www.airra.org. (accessed. September 10, 2012). Place Published.

Huth, N. I., B. Cocks, N. Dalgliesh, P. L. Poulton, O. Marinoni and J. N. Garcia. 2017. Farmers' perceptions of coexistence between agriculture and a large scale coal seam gas development. Agriculture and Human Values, 35: 99-115.

Lehmann, F. and P. Saran. 1975. The Provincial Government of the Mughals, 1526-1658. Pacific Affairs, 48: 276.

Manu, I. N., M.-J. Bime, D. E. Fon and A. Nji. 2014. Effects of farmer-grazer conflicts on rural development: a socio-economic analysis. Sch J Agric Sci, 4: 11-120.

Maturo, A., E. Sciarra and A. G. S. Ventre. 2010. Counselling: Decision Making, Consensus, and Mediation. Procedia - Social and Behavioral Sciences, 5: 1770-76.

Mehmood, C. S. and A. G. Chaudhry. 2015. Justice through Mediation: Revitalizing Informal Justice System. The explorer: Journal of Social Sciences, 1: 94-96.

Namande, W. 2008. Information application in resolving ethnic strife in cohesions in C.M. Nyamboga and Kenyan Library Association. pp.117-138. Place Published.

Neef, A., L. Chamsai, M. Hammer, A. Wannitpradit, C. Sangkapitux, Y. Xyooj, P. Sirisupluxuna and W. Spreer. 2004. Water Tenure in Highland Watersheds of Northern Thailand: Tragedy of the Commons or Successful Management of Complexity? Springer Berlin Heidelberg. Place Published. pp.367-90.

Ofuoku, A. U. and B. I. Isife. 2009. Causes, effects and resolution of farmers-nomadic cattle herders conflict in Delta state, Nigeria. International journal of sociology and Anthrapology, 1: 47-54.

Shan, L., A. T. W. Yu and Y. Wu. 2017. Strategies for risk management in urban-rural conflict: Two case studies of land acquisition in urbanising China. Habitat international, 59: 90-100.

Siddik, M. A., M. A. Rahman and M. Moniruzzaman. 2018. Causes and Consequences of Land Disputes in the Coastal Area of Bangladesh. Eastern Geographer, 24: 7-15.

Usman, S., A. Saghir, K. M. Ch, I. Ashraf and A. Rani. 2020. Assessment of multi-actor stakeholders' role in conflict resolution in Punjab, Pakistan. International Journal of Agricultural Extension, 7: 207-10.

Walker, S. 2002. Mediating citizen complaints against police officers: A guide for police and community leaders. US Department of Justice, Office of Community Oriented Policing Services.

Wilmot, W. W. and J. L. Hocker. 2010. Interpersonal conflict. McGraw-Hill Higher Education.

Yamano, T. and K. Deininger. 2005. Land conflicts in Kenya: causes, impacts, and resolutions. Foundation for Advanced Studies on International Development/National Graduate Institute for Policy Studies. The World Bank, 28. 
Publisher's note: EScience Press remains neutral with regard to jurisdictional claims in published maps and institutional affiliations.

(c)

Open Access This article is licensed under a Creative Commons Attribution 4.0 International License, which permits use, sharing, adaptation, distribution and reproduction in any medium or format, as long as you give appropriate credit to the original author(s) and the source, provide a link to the Creative Commons license and indicate if changes were made. The images or other third-party material in this article are included in the article's Creative Commons license, unless indicated otherwise in a credit line to the material. If material is not included in the article's Creative Commons license and your intended use is not permitted by statutory regulation or exceeds the permitted use, you will need to obtain permission directly from the copyright holder. To view a copy of this license, visit http://creativecommons.org/licenses/by/4.0/. 